\title{
CHARACTERIZATION OF CLASS 1 INTEGRONS AND SOME ANTIMICROBIAL RESISTANCE GENES IN Salmonella SPECIES ISOLATED FROM POULTRY IN EGYPT
}

\author{
Safaa M. Shabana ${ }^{1 *}$, Salwa M. Helmy², Abd El-Halem M. Hegazy³
}

${ }^{1}$ Department of Microbiology, Animal Health Research Institute, Kafr El Sheikh branch, Agriculture research center, Giza, Egypt, ${ }^{2}$ Department of Bacteriology, Mycology and immunology, Faculty of Veterinary Medicine, Kafrelsheikh University, Egypt, ${ }^{3}$ Department of Poultry Disease, Animal Health Research Institute, Kafr El Sheikh branch, Agriculture research center, Giza, Egypt

*Corresponding author, E-mail: sofy.shabana@yahoo.com

\begin{abstract}
Salmonella enterica includes serotypes that were implicated as a food borne pathogens crucially affecting public health and the economic organization. This study was directed to isolate and identify of Salmonella strains from 222 different species and ages of poultry (broiler, chick, ducks, pigeon, quails) from Kafr El Sheikh governorate. The Salmonella isolation rate was $(4.5 \%)$ as $(0.9 \%)$ from apparently healthy, $(3.6 \%)$ from diseased birds. The outer membrane protein $\mathrm{F}$ gene was used as promising tool for detection of Genus Salmonella, after that four isolates were identified serologically as two Salmonella enterica serovar Enteritidis and two Salmonella enterica serovar Typhimurium. The resistance pattern of positive Salmonella isolates showed multidrug resistance phenotypes and qnrS for quinolone resistant genes was recorded in one isolate while blaTEM for $\beta$-lactam resistant isolates, aacC for aminoglycosides were recorded in all four Salmonella isolates using PCR technique. Also, Class 1 integrons detected with a percentage of $(100 \%)$ in examined isolates. Sequencing of the class 1 integrons cassettes showed genes encoding resistance specified to streptothricin acetyltransferase (sat) gene, aminoglycoside acetyltransferase (aac3-ld) and aminoglycoside adenyltransferase (aadA7). Class 1 integrons harbored gene encoding domains unfunction protein (duf) in one $S$. enterica serovar Typhimurium isolate. This study spotlights the significant role of the drug-resistance genes and Class 1 integrons in Salmonella as zoonotically important pathogens of public health importance.
\end{abstract}

Key words: poultry; Salmonella; drug- resistance genes; integrons gene cassettes

\section{Introduction}

Salmonella include approximately 2500 serovars. Salmonella enterica represents the most of the Salmonella serovars and Salmonella enterica serovar Enteriditis was the most popu- lar serovar with a zoonotic effect, then Salmonella enterica serovar Typhimurium (1). Globally, Salmonella enterica subsp. Enterica included serotypes that have economically and public health significantly effects (2). The most non-typhoidal salmonellosis (NTS) cases related to consuming of contaminated animal 
origin foods, especially fowl, meat and in some cases vegetables (3). Poultry considered an important reservoir of many zoonotically important pathogens, such as Salmonella, which acted as a prime importance (4).

The pore-forming proteins of Salmonella and other Gram negative bacteria outer membrane (OM) called porins (5). Among OMPs (outer membrane proteins), the outer membrane protein $\mathrm{F}(\mathrm{ompF})$ and outer membrane protein $\mathrm{C}($ ompC) were the most types porins that represented $2 \%$ of the total porins, and $o m p F$ was the most ideal structural and functional characterization porin protein (6). Also, the ompF gene was used as a promising tool for detection of Salmonellae where it could discriminate genus Salmonella from other non-Salmonella organisms in clinical samples (7).

Multidrug resistant (MDR) non-typhoidal Salmonella (NTS) might be transmitted from the poultry to human through the food series, whilst the antimicrobial resistance (AMR) could be carried among bacteria throughout the resistance genes associated with integrons and another mobile genetic elements as plasmids and transposons (8). Avian Salmonella showed resistance against many antimicrobial groups such as $\beta$-lactam, aminoglycosides and quinolones (9).

Salmonella species associated with $q n r$ genes were isolated from the poultry field might cause a harmful effect on the public health because these could be transmitted to humans via poultry products or by contact with poultry and could rapidly increase fluoroquinolone resistance in various bacterial species through the transfer of plasmids harboring $q n r$ genes. (10). The resistance to aminoglycosides as Gentamicin could confer using the aminoglycoside acetyltransferase $(a a c)$ genes which were detected in numerous isolates of Salmonella (11).

The class 1 integrons played a character in the presence of AMR in Salmonella enterica which might isolate from broilers, meat and hogs products (12). Class 1 integrons, the most communal integron located on Salmonella genomic island 1 (SGI 1), was found in various Salmonella serovars, including $\mathrm{S}$. enterica serovar Typhimurium; S. enterica serovar Newport and S. enterica serovar Oslo. (13).

The classes of integrons which might be recovered from GenBank were nine, but the first four categories had been sustained only. Cass 1 integrons was widely distributed among the family Enterobacteriaceae organisms (14). These integrons include two conserved segments (5' CS and 3' CS) separated by a variable region that normally comprises one or more gene cassettes. Integrons encompass three important parts: an integrase gene (IntII); an adjacent attachment site (attI1) and a promoter region (PC) (15). An open reading frame (ORFs) where a specific site containing a modular structure called gene cassettes (16). The collection of gene cassettes (up to nearly half a dozen) had related the integrons with MDR (17).

This study highlighted the importance of the strains of Salmonella, which isolated from different species and age poultry as zoonotically important pathogen, some antimicrobial drug resistance genes of Salmonella species and class 1 integrons gene cassettes in this public health importance organism.

\section{Materials and methods}

\section{Collection of samples and isolates charac- terization}

In this work, which was conducted from April 2017 to April 2018, a total of 222 apparently healthy (56) and diseased (166) from different species and ages of poultry (Broiler, chick, ducks, pigeon, quails) from the Kafr El Sheikh governorate. The internal organs (liver, spleen, gall bladder, ileocaecal tonsil, yolk sac), cloacal swabs and the pooled samples. Samples were transferred to the laboratory in an ice tank within 2 hours for bacteriological isolation and identification (18), then confirmed biochemically by the API $20 \mathrm{E}$ system.

\section{Serological identification}

Biochemically suspected isolates were serotyped according to Kauffman (19) at Serological unit in Institute of Animal Health Research,Giza, Egypt. 
Identification of genus Salmonella using ompF gene

Programming of PCR to amplify ompF gene was used as promising tool for detection of genus Salmonella was done according to Tatavarthy and Cannons (20) using oligonucleotide primers in Table 1.

\section{Antimicrobial susceptibility}

The susceptibility test of samples were done as Finegold and Martin, (21). A total of 11 antimicrobial discs was used for sensitivity (Oxoid) were Amoxicillin-clavulanic acid (AMC), $30 \mu \mathrm{g}$; Cefotaxime (CTX), $30 \mu \mathrm{g}$; Ceftazidime (CAZ), $30 \mu \mathrm{g}$; Chloramphenicol (C), $30 \mu \mathrm{g}$; Ciprofloxacin (CIP), $5 \mu \mathrm{g}$; Gentamicin (CN), $10 \mu \mathrm{g}$; Nalidixic acid (NA),30 $\mu \mathrm{g}$; Spectinomycin (SH), $10 \mu \mathrm{g}$; Colistin (CT), $10 \mu \mathrm{g}$; Norfloxacin (NOR), $10 \mu \mathrm{g}$ and Doxycycline (DO), 30 $\mu \mathrm{g}$. Interpretation as resistant, moderately susceptible or susceptible as recorded in the Clinical and Laboratory Standards Institute CLSI (22).

\section{Molecular analysis of antimicrobial re- sistance genes}

The DNA extraction was done using QIAamp DNA Mini Kit (Catalogue no. 51304) according to manufactures' guidelines. The primer sequences for detection of aacC gene (encoded for aminoglycoside resistance) (23), $q n r S$ gene (encoded for quinolones resistance) (24), blaTEM gene (encoded for $\beta$-lactams resistance) (25) and class 1 integrons gene cassettes (26) (Table 1).

Sequencing screen for class 1 integrons gene cassettes

QIAquick kit. (Qiagen Inc. Valencia, CA): It was used for purification of the PCR product from $1.5 \%$ agarose gels. Applied Biosystems 3130 automated DNA Sequencer $(A B I, 3130$, USA). Identification similarity of nucleotide and amino acid sequences between Salmonella strains and other Enterobacteriacae recorded in GenBank was done using (National Center for Biotechnology Information "NCBI"). Using the BioEdit sequence alignment editor for compar- isons of the nucleotide sequences (27). Phylogenetic analysis was done using ClustalW (http://www.ebi.ac.uk/clustalw/).

\section{Results}

The incidence of Salmonellae from different samples

The obtained results of Salmonella isolation revealed that $10(4.5 \%)$ were positive for Salmonella identified biochemically out of 222 examined birds, The isolation rates from chicken, ducks and quails were 8 of 156 samples $(5.1 \%)$, 1 of 35 samples $(3.2 \%)$ and 1 of 2 samples $(50 \%)$, respectively, while could no isolation of Salmonella from chick and pigeon samples. The positive biochemically Salmonella isolates from different samples represented in 4 out of $100(4 \%), 2$ out of $51(3.9 \%), 2$ out of 36 (5.5\%), 1 out of $19(5.2 \%)$ and 1 out of 2 (50 $\%)$ from cloacal swabs, pooled samples, liver, gall bladder and yolk sac samples respectively, while the isolation from the spleen and ileocecal tonsil samples was negative for Salmonellae (Table 2).

\section{Serotyping of Salmonella isolates}

Four isolates from ten biochemically positive suspected Salmonella isolates were classified under two different serotypes, including two Salmonella enterica serovar Enteritidis were isolated from cloacal swab of chicken and duck and Salmonella enterica serovar Typhimurium isolated from the quail yolk sac and chicken liver samples.

\section{Antimicrobial susceptibility}

Salmonella isolates showed resistance to Gentamycin, Ciprofloxacin, Doxycycline, Spectinomycin and Colistin with (50\%), however, showed sensitive to Ceftazidime with (100\%), followed by Cefotaxime by (75\%), amoxicillin clavulinic acid, Nalidixic acid, Chloramphenicol and Norofloxacine with (50\%) (Table 3). Two non-typhoidal Salmonella isolates showed multidrug resistant (MDR) phenotypes to five different antibiotic classes (Table 3). 
Detection of genus Salmonella using OmpF gene by PCR

All examined Salmonella isolates was positive at $519 \mathrm{bp}$ of $o m p F$ using the PCR technique with a percentage of $(100 \%)$ (Fig. 1).

\section{Antimicrobial resistance encoding genes}

The phenotypic antimicrobial resistant Salmonella isolates was analyzed by PCR technique to key out some resistance coding genes. The positive percentage of $q n r S$ gene for quinolone resistant was (25\%), where blaTEM for $\beta$-lactam resistant gene, aac $C$ for aminoglycosides resistant gene and Class 1 integrons were (100\%) (Fig. 1).
Class 1 integrons sequencing of the variable amplicons showed the gene cassettes containing streptothricin acetyltransferase (sat) gene encoding resistance against Streptothricin (an early aminoglycoside) in two Salmonella serovars isolated in the current work, but aminoglycoside acetyltransferase (aac(3)-Id) and aminoglycoside adenyltransferase (aadA7) genes which encoding resistance against Gentamycin and to streptomycin and spectinomycin, respectively in isolate of $S$. enterica serovar Typhimurium only. One S. enterica serovar Typhimurium isolate Class 1 integrons harbored gene encoding domains of unknown function protein $(d u f)$.

Table 1: Oligonucleotide primers used for detection of $o m p F$, antimicrobial resistance coding genes (aac $C, q n r S$ and blaTEM) and class 1 integrons cassettes

\begin{tabular}{|c|c|c|c|}
\hline Gene & Primer sequence (5'-3') & $\begin{array}{l}\text { Length of ampli- } \\
\text { fied product }\end{array}$ & Reference \\
\hline ompF & $\begin{array}{c}\text { Forward- CCTGGCAGCGGTGATCC } \\
\text { Reverse- TGGTGTAACCTACGCCATC }\end{array}$ & $519 \mathrm{bp}$ & $\begin{array}{l}\text { Tatavarthy and Can- } \\
\text { nons, (20) }\end{array}$ \\
\hline aacC & $\begin{array}{l}\text { Forward- GGCGCGATCAACGAATTTATCCGA } \\
\text { Reverse- CCATTCGATGCCGAAGGAAACGAT }\end{array}$ & $448 \mathrm{bp}$ & Lynne et al., (23) \\
\hline$q n r S$ & $\begin{array}{l}\text { Forward- ACGACATTCGTCAACTGCAA } \\
\text { Reverse- TAAATTGGCACCCTGTAGGC }\end{array}$ & $417 \mathrm{bp}$ & Robicsek et al., (24) \\
\hline blaTEM & $\begin{array}{c}\text { Forward- ATCAGCAATAAACCAGC } \\
\text { Reverse- CCCCGAAGAACGTTTTC }\end{array}$ & $516 \mathrm{bp}$ & Colom et al., (25) \\
\hline $\begin{array}{l}\text { class } 1 \text { integron } \\
\text { cassettes }\end{array}$ & $\begin{array}{l}\text { Forward- GGC ATC CAA GCA GCA AG } \\
\text { Reverse- AAAG CAG ACT TGA CCT GA }\end{array}$ & Variable & Sow et al., (26) \\
\hline
\end{tabular}

Table 2: The incidence of Salmonellae isolated from different organs and identified biochemically

\begin{tabular}{|c|c|c|c|c|c|c|c|c|c|c|}
\hline \multirow[t]{2}{*}{$\begin{array}{l}\text { Poultry } \\
\text { species }\end{array}$} & \multicolumn{7}{|c|}{ Organs samples } & \multirow[t]{2}{*}{$\begin{array}{c}\text { Samples } \\
\text { No. }\end{array}$} & \multicolumn{2}{|c|}{$\begin{array}{c}\text { positive sam- } \\
\text { ples }\end{array}$} \\
\hline & $\begin{array}{c}\text { Cloacal } \\
\text { swab }\end{array}$ & $\begin{array}{l}\text { *Pooled } \\
\text { samples }\end{array}$ & liver & Spleen & $\begin{array}{c}\text { Gall } \\
\text { bladder }\end{array}$ & $\begin{array}{c}\text { Yolk } \\
\text { sac }\end{array}$ & $\begin{array}{c}\text { iliocecal } \\
\text { tonsil }\end{array}$ & & No. & $\%$ \\
\hline Chicken & 67 & 34 & 29 & 7 & 17 & - & 2 & 156 & 8 & $5.1 \%$ \\
\hline Chicks & 6 & 5 & 2 & 2 & - & 1 & 3 & 19 & - & $0 \%$ \\
\hline Duck & 19 & 10 & 4 & - & 2 & - & - & 35 & 1 & $3.2 \%$ \\
\hline Pigeon & 8 & 2 & - & - & - & - & - & 10 & - & $0 \%$ \\
\hline Quails & - & - & 1 & - & - & 1 & - & 2 & 1 & $50 \%$ \\
\hline Total & $\begin{array}{c}100 \\
(4 \%)\end{array}$ & $\begin{array}{c}51 \\
(3.5 \%)\end{array}$ & $\begin{array}{c}36 \\
(5.5 \%)\end{array}$ & $\begin{array}{c}9 \\
(0 \%)\end{array}$ & $\begin{array}{c}19 \\
(5.2 \%)\end{array}$ & $\begin{array}{c}2 \\
(50 \%)\end{array}$ & $\begin{array}{c}5 \\
(0 \%)\end{array}$ & 222 & 10 & $4.5 \%$ \\
\hline
\end{tabular}

*Pooled samples from different organs of poultry submitted to Kafr El Sheikh lab. For examination 
Table 3: Antimicrobial resistance patterns, resistance genes and class 1 integron profiles of Salmonella serotypes in this study

\begin{tabular}{|c|c|c|c|c|c|c|c|}
\hline $\mathrm{NO}$ & $\begin{array}{c}\text { Serovars } \\
\text { (source of isolates) }\end{array}$ & Resistance pattern & $\begin{array}{c}* * \text { MDR } \\
\text { isolates } \\
\mathrm{N}(\%) \\
\end{array}$ & $\begin{array}{l}\text { Resistance } \\
\text { genes }\end{array}$ & $\begin{array}{l}\text { Integron } \\
\text { amplicon } \\
\text { size (bp) }\end{array}$ & $\begin{array}{l}\text { Genes } \\
\text { cassettes }\end{array}$ & $\begin{array}{l}\text { Accession } \\
\text { numbers }\end{array}$ \\
\hline 1 & $\begin{array}{l}\text { S. enterica serovar } \\
\text { Enteritidis (duck) }\end{array}$ & $\mathrm{CT}$ & - & $\begin{array}{c}\text { blaTEM, } \\
\text { aac } \mathrm{C}\end{array}$ & + & - & - \\
\hline 2 & $\begin{array}{l}\text { S. enterica serovar } \\
\text { Enteritidis (chicken) }\end{array}$ & $\begin{array}{c}\mathrm{CN}, \mathrm{DO}, \mathrm{C}, \mathrm{CT}, \\
\text { CIP }\end{array}$ & + & $\begin{array}{c}\text { blaTEM, } \\
\text { aac } \mathrm{C}\end{array}$ & 600 & sat & MK335377 \\
\hline 3 & $\begin{array}{l}\text { S. enterica } \text { serovar } \\
\text { Typhimurium (quail) }\end{array}$ & $\mathrm{SH}$ & - & $\begin{array}{c}\text { blaTEM, } \\
\text { aacC }\end{array}$ & 800 & $d u f$ gene & MK359461 \\
\hline 4 & $\begin{array}{l}\text { S. enterica serovar } \\
\text { Typhimurium } \\
\text { (chicken) }\end{array}$ & $\begin{array}{l}\text { CN, NOR, DO, } \\
\text { AMC, CIP, SH }\end{array}$ & + & $\begin{array}{l}\text { blaTEM, } \\
\text { aacC, qnrS }\end{array}$ & $\begin{array}{l}650 \\
1600 \\
1800\end{array}$ & $\begin{array}{c}\text { sat } \\
\text { aac3-Id,aadA7 } \\
\text { aadA7 }\end{array}$ & $\begin{array}{l}\text { MK349001 } \\
\text { MK349002 } \\
\text { MK359462 }\end{array}$ \\
\hline & Total & & $2(50 \%)$ & & & & \\
\hline
\end{tabular}

***Multidrug resistant (MDR) Salmonella isolates were 2(50\%) to five different antibiotic classes
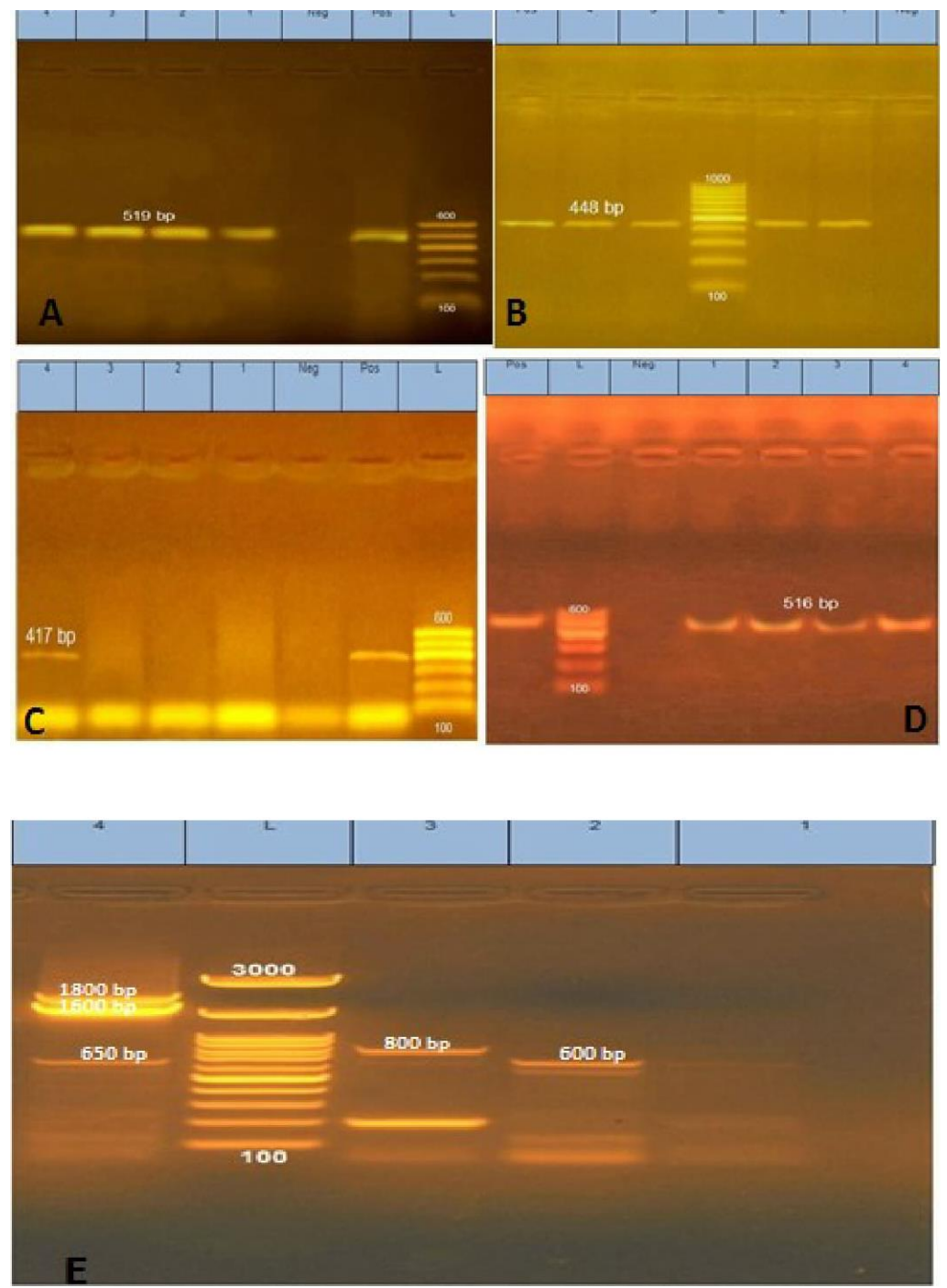

Figure 1: PCR amplification of the different genes in this study; "Pos" stands for positive control, "Neg": Negative control; L: 100 bp DNA ladder; Lane (1, 2, 3, 4) examined Salmonella isolates. A. ompF gene(519 bp). Resistance associated genes, B. aacC gene (448bp). C. qnrS gene (417bp). D. blaTEM gene (516 bp). E. Class 1 integrons at variable sizes in Salmonella isolates 


\section{Discussion}

Salmonella represents a critical problem to livestock in countries where not interest to the control measures or in those where the environmental conditions help in the development of these microorganisms (28).

In the present study, Salmonella spp. were isolated and identified from different species and ages of poultry and molecular characterized for many important antimicrobial resistance genes and class 1 integrons of Salmonella species.

The results indicated that $10(4.5 \%)$ isolates out of 222 examined bird suspected to be Salmonella isolates from 166 diseased birds and 56 apparently healthy birds with the percentage of $(3.6 \%)$ and $(0.9 \%)$, respectively by phenotypic and biochemical characterization that agree with report in Egypt where $4.4 \%$ were positive for Salmonella isolated from poultry farms (7), but higher than those of Salmonella isolation from small poultry farms with $(1.6 \%)$ in California (29), and lower than (8.65\%) of Salmonella isolated from poultry (30) .

The consequence of isolation appears to be high from the diseased bird than apparently healthy bird 8vs 2, although the samples were gathered up from each of diseased and apparently healthy birds together. These variations in the overall prevalence of Salmonella may be related to several factors such as environment, hygienic conditions of the farm and health status of the examined bird $(31,32)$ which leading to the bird become weaker and therefore are easily infected by Salmonella. Similarly, Salmonella was isolated from apparently healthy chickens lower than from diseased chickens in Shanghai and in Egypt $(32,33)$.

Currently, the isolation percentages from chicken, ducks and quails were 8 of 156 samples $(5.1 \%), 1$ of 35 samples $(3.2 \%)$ and 1 of 2 samples $(50 \%)$, respectively, were positive for Salmonella strains while the chick and pigeon samples were negative for Salmonellae which are not compatible with (7.25\%) Salmonella incidence from chickens and $(15.55 \%)$ of pigeons (30) and also with percentage $(6 \%)$ in ducks in Egypt (34).
The high Salmonella isolation rate of liver and gallbladder samples 2 of 36 samples $(5.5 \%), 1$ out of 19 samples (5.2\%), respectively agrees with the highest rate of Salmonella isolation from liver samples $(35,36)$. All spleen and ceca samples were negative for Salmonellae that agree with another study on Salmonella was not isolated from spleen samples (37) but also, disagree with those isolated the highest Salmonella percentage from spleen samples in Egypt (38).

It is common knowledge that the cloacal swab is considered a particular signal of incessant intestinal colonization in poultry, but its diagnostic accuracy is minimized where the Salmonella infected birds are intermittent shedding via feces (39).

In present the study the four isolated Salmonellae were classified under two different serovars, Salmonella enterica serovar Enteritidis and Typhimurium with a percentage of 2 of $4(50 \%)$ for each.

The difference between the results of serological and bacteriological examination to identify Salmonella assigned to Salmonella give identical colony morphology on S.S agar and biochemical reactions with the other members of the family Enterobacteriaceae and this difference consistent with the opinion of there are problems in the biochemical identification reactions (40). Similarly, there were differences in the identification of Salmonella spp. as used conventional techniques was $(10.5 \%)$, the API $20 \mathrm{E}$ system was $(9 \%)$ and by serotyping was (7.8\%) (35).

The serological identification result referred to an isolation of two serotypes, Salmonella enterica serovar Typhimurium and Enteritidis, similar that reported in central Ethiopia (41) and Egypt (42) where they isolated only Salmonella enterica serovar Enteritidis and Typhimurium, but disagrees with a previous study on $S$. enterica serovar Enteritidis isolated from commercial layer farms (43).

The phenotype antimicrobial resistance result was resistant to $(\mathrm{CN}),(\mathrm{CIP}),(\mathrm{DO}),(\mathrm{SH})$ and (CT) with a percentage $(50 \%)$. Moreover, the isolates were sensitive to (CAZ) with $(100 \%)$, followed by (CTX) with $(75 \%)$ then 
(AMC), (NAL), (C) and (NOR) with (50\%). These results concur with study reported that the resistance to Gentamycin was observed in (39.58\%) (44) and those reported that the resistance to Tetracycline, Ciprofloxacin and Spectinomycin was $(51.9 \%),(48.7 \%)$ and (34.4\%), respectively (45), but disagree with those reported that Gentamycin inhibited to all Salmonella strains and resistance of Ciprofloxacin with a percentage (10\%) (46).

The high sensitivity to Ceftazidime (100\%), followed by Cefotaxime (75\%) in the present work agrees with the previous reports described a low Cephalosporin resistance prevalence of $S$. enterica serovar Enteritidis in Kohat and Egypt $(47,48)$. Two non-typhoidal Salmonella isolates $(50 \%)$ showed multidrug resistant (MDR) phenotypes to at least five various antibiotic types which similar with another study reported that the multidrug resistant Salmonella isolates represented 55\% in Malaysia (49).

The outer membrane protein $\mathrm{F}(\mathrm{ompF})$ gene detected in the examined isolates in this current study with a percentage of $(100 \%)$ using the PCR technique. The ompF gene considers a good tool for fast identification of Salmonella, so omp $F$ mutation or loss might lead to mistakes in the identification analyze of Salmonella strains (20). Similarly, using the ompF gene as a tool for detection of Salmonella genus in Egyptian poultry farms (7).

Poultry acts as a carrier of multidrug resistant Salmonella and this no related to resistance genes presence, so other acquiring resistance mechanisms might be present (50). The detection result of resistance coding genes (blaTEM and $a a c C$ ) was (100\%) and this disagrees with a previous report detected blaTEM in $S$. enterica serovar Typhimurium isolates only in Japan (51), also with another report detected aacC gene with (30\%) of Salmonella isolates in broiler in Egypt (52). The result of the current study similar to another study detected the blaTEM gene with (93.3\%) in Salmonella isolates obtained from commercial layers in Egypt (31). The qnrS gene, a gene quinolone resistant was reported in the present work with the percentage of $(25 \%)$ that parallel with the result of another study in Egypt (31).
The differences in phenotypic-genetic antibiotic resistance results recorded in this study of Salmonella isolates was also registered in other reports (53), and was usually mentioned to either existence of resistance alternative mechanisms or defect in the resistant genes expression .

The result of Class 1 integrons detection was $(100 \%)$ of this work, similarly, the result of Class 1 integrons detection of Salmonella isolated from Egypt (54).

The sat gene was detected within class 1 integrons of $S$. enterica serovar Enteritidis (chicken, 600bp) and S. enterica serovar Typhimurium (chicken, 650bp) in this investigation was preceding identity in $S$. Typhimurium (KT449570) in Egypt (54), S. Choleraesuis (EU834941) in southern Taiwan (55), other family Enterobacteriaceae organisms class 1 integrons as, Shigella sonnei from western Ireland (AY090896) (56), E.coli plasmid (CP022735) (57), and other bacteria as, in Vibrio alginolyticus plasmid (KU160531) (58). The aac (3)-Id and aadA7 genes had been identified in class 1 integrons gene cassettes of ( $S$. Typhimurium, chicken) showed a preceding identity in class1 integrons of $S$. Derby (KT427378), S. enterica (KT581256) in Egypt (54).

In the current investigation, the detection of sat, aac (3)-Id and aadA7 genes within class1 integrons of isolated Salmonella may be related to the extensive using the aminoglycoside antibiotics group in poultry farms.

The domains of unknown function protein (duf) gene was identified in class 1 integrons gene cassettes of ( $S$. Typhimurium, quail) in the current work, which difficult to decide its function due to lack of its protein sequences identity with interpreted biochemical function. The $d u f$ gene represents more than (20\%) of all protein domains (59).

The class 1 integrons cassettes sequencing of the two isolated Salmonella serovars in this current investigation were documented into the GenBank with accession numbers (MK335377); (MK349001); (MK349002), (MK359462) and (MK MK359461). 


\section{Conclusion}

Poultry acts as the important reservoir of many zoonotically important pathogens, such as Salmonella and detection of resistance genes related to significant antimicrobial drugs which used in the medical establishments. Integrons cassettes carrying antimicrobial resistance genes in Salmonella have an important role in the spreading of AMR so, the strategy used to control of using of antimicrobial drugs against this organism as well as other emerging pathogens of public health importance should be improved.

\section{Acknowledgments}

The authors would like to thank the staff members of Microbiology Department, Faculty of Veterinary Medicine, Kafrelsheikh University, Egypt and Bacteriology unit, Kafr El Sheikh Animal Health Research Institute, Egypt who supported this investigation and facilitated this work.

\section{Conflict of interest}

The authors declare that they have no conflict of interest.

\section{References}

1. Amagliani G, Brandi G, Schiavano GF. Incidence and role of Salmonella in seafood safety. F Res Int 2012; 45:780-8.

2. Scallan E, Hoekstra RM, Angulo FJ, Tauxe RV, Widdowson MA, Roy SL, Jones JL, Griffin $\mathrm{PM}$. Foodborne illness acquired in the United States-major pathogens. Emerg Infect Dis 2011; 17(1):7-15.

3. Antunes P, Mourao J, Campos J, Peixe L. Salmonellosis: The role of poultry meat. Clin Microbiol Infect 2016; 22:110-21.

4. European Food Safety Authority. The European Union summary report on

trends and sources of zoonoses, zoonotic agents and food-borne outbreaks in 2010. EFSA J 2012; 10(3): 2597.

5. Baalaji NS, Mathew MK, Krishnaswamy S. Functional assay of Salmonella Typhi ompC using reconstituted large unilamellar vesicles: a general method for characterization of outer membrane proteins. Bio chemie 2006; 88: 1419-24.

6. Williams KM, Bigley EC, Raybourne RB. Identification of murine $\mathrm{B}$-cell and T-cell epitopes of Escherichia coli outer membrane protein $\mathrm{F}$ with synthetic polypeptides. Infect Immun 2000; 68:2535-45.

7. Abd El- Tawab AA, Ahmed MA, Amany IE, Mai ME. A study of outer membrane protein (OMPs) genes for detection of salmonella organisms in poultry farms. BVMJ 2016; 30 (1): 231-7.

8. Ben Salem R, Abbassi MS, Garcia V, GarciaFierro R, Fernandez J, Kilani

H, Jaouani I, Khayeche M, Messadi L, Rodicio MR. Antimicrobial drug resistance and genetic properties of Salmonella enterica serotype Enteritidis circulating in chicken farms in Tunisia. J Infect Public Health 2017; 10 (6): 855-60.

9. Taddele MH, Rathore R, Dhama K. Antibiogram assay of $S$.Gallinarum and other $S$. Enteric serovars of poultry origin in India. J Anim Vet Adv 2012; 7: 309-17.

10. Kim JH, Cho JK, Kim KS. Prevalence and characterization of plasmid-mediated quinolone resistance genes in Salmonella isolated from poultry in Korea. Avian Pathol 2013; 42(3): 221-9.

11. Frye JG, Jackson CR . Genetic mechanisms of antimicrobial resistance identified in Salmonella enterica, Escherichia coli, and Enteroccocus spp. isolated from U.S. food animals. Front Microbiol 2013; 4: 135.

12. Trongjit S, Angkititrakul S, Tuttle RE, Poungseree J, Padungtod P, Chuanchuen R. Prevalence and antimicrobial resistance in Salmonella enterica isolated from broiler chickens, pigs and meat products in Thailand-Cambodia border provinces. Microbiol Immunol 2017; 61(1): 23-33.

13. Kakatkar AS, Pansare LS, GautamRK, Shashidhar R, Karani M, Bandekar JR. Molecular characterization of antibiotic resistant Salmonella isolates from Indian foods. Food Res Int 2011; 44(10):3272-5.

14. Phongpaichit $S$, Wuttananupan K, Samasanti W. Class1 integrons and multidrug resistance among Escherichia coli isolates from human stools. Southeast Asian J Trop Med Public Health 2008; 39 (2): 279-87.

15. Carattoli A. Importance of integrons in the diffusion of resistance. Veterinary Research, BioMed Central 2001; 32 (3-4): 243-59.

16. Labbate M, Case RJ, Stokes HW. The integron gene cassette system: an active player in bacterial adaptation. Methods Mol Biol 2009; 532: 103-25.

17. Leverstein-van MA, Blok HE, Donders AR, Paauw A, Fluit AC, Verhoef J. 
Multidrug resistance among Enterobacteriaceae is strongly associated with the presence of integrons and is independent of species or isolate origin. J Infect Dis 2003; 187 (2): 251-9.

18. International Standards Organization (ISO 6579). General guidance on methods for the detection of Salmonella, Geneva, Switzerland, 2002.

19. Kauffman G. Kauffmann white scheme. J Acta Path Microbiol Sci 1974; 61: 38.

20. Tatavarthy A, Cannons A. Real-time PCR detection of Salmonella species using a novel target: the outer membrane porin F gene $(o m p F)$. Lett Appl Microbiol 2010; 50 (6): 645-52.

21. Finegold SM, Martin WJ. Diagnostic microbiology. 6th Ed., The C.V. Mosby Company, St. Louis, Toronto, London, 1982.

22. CLSI. Performance Standards for Antimicrobial Susceptibility Testing; Twenty- Fifth Informational Supplement (M100 - S25), Clinical and Laboratory Standards Institute. Pennsylvania 19087, USA, 2015; 44-50j

23. Lynne AM, Rhodes-Clark BS, Bliven K, Zhao S, Foley SL. Antimicrobial Resistance Genes Associated with Salmonella enterica serovar Newport isolates from Food Animals. Antimicrob Agents Chemother 2008; 52(1): 353-6.

24. Robicsek A, Strahilevitz J, Jacoby GA, Macielag M, Abbanat D, Park CH, Bush K, Hooper DC. Fluoroquinolone modifying enzyme: a new adaptation of a common aminoglycoside acetyltransferase. Nat MED 2006; 12 (1): 83 -88.

25. Colom K, Pèrez J, Alonso R, FernándezAranguiz A, Lariňo E, Cisterna R. Simple and reliable multiplex PCR assay for detection of blaTEM, blaSHV and blaOXA-1 genes in Enterobacteriaceae. FEMS Microbiol Lett 2003; 223 (2):147-51.

26. Sow AG, Wane A, Diallo MH, Boye CS, Aïdara-Kane A. Genotypic characterization of antibiotic-resistant Salmonella Enteritidis isolates in Dakar, Senegal. J Infect Developing Countries 2007; 1 (3): 284-8.

27. Hall A. BioEdit: a user-friendly biological sequence alignment editor and analysis program for Windows 95/98/NT. Nuc Acids Symp Ser 1999; 41: 95-8.

28. Barrow PA, Freitas Neto OC. Pullorum disease and fowl typhoid new thoughts on old diseases. Avian Pathol 2011; 40 (1): 1-13.

29. Clothier KA, Kim P, Mete A, Hill AE. Frequency, serotype distribution and antimicrobial susceptibility patterns of Salmonella in small poultry flocks in California. J Vet Diagn Invest 2018; 30 (3): 471- 475.
30. Akbarmehr J. Isolation of Salmonella spp. from poultry (ostrich, pigeon, and

chicken) and detection of their hilA gene by PCR method. A J Microbiol Res 2010; 4 (24): 26782681.

31. Lebdah MA, Waffa MM, Samah E, Rehab IH. Molecular detection of some

Antimicrobial Resistance Genes in Salmonella species isolated from commercial layers in Egypt. Zagazig Vet J 2017; 45(1): 29-38.

32. Liu W B, Chen J, Huang YY, Liu B, ShiX M. Serotype, genotypeand antimicrobial susceptibility profiles of Salmonella from chicken farms in Shanghai. J Food Prot 2010; 73(3): 562-567.

33. Abd El-Ghany WA, Soumaya SA, ElShafiiHatem ME. A survey on Salmonella species isolated from chicken flocks in Egypt. AJAVA 2012; 7 (6): 489-501.

34. Ibrahim MA, Emeash HH, Nahed HG, Abdel-Halim MA. Seroepidemiological Studies on Poultry Salmonellosis and its Public Health Importance. J World's Poult Res 2013; 3 (1): 18-23.

35. AL-Iedani AA, Khudor MH, Oufi NM. Isolation and identification of Salmonella spp. from poultry farms by using different techniques and evaluation of their

antimicrobial susceptibilities. Bas J Vet Res 2014; 13(1): 246-259.

36. Dhaher FH, Awni MDH, Mahmood NR, Jamil MM. Isolation and diagnosis of

Salmonella in Animal origin food. Iraq Acad Sci J 2011; 3(5):1-19.

37. Marwa RA. Molecular characterization of some Antibiotic Resistance Genes in Salmonella Species isolated from diseased poultry. MVSc thesis, Fac of Vet Med, kafrelsheikh Univ, Egypt, 2016.

38. Orady M R, Salwa MH, Ahmed MAA, Wafaa MH, Etab MA, Azza S E. Molecular Characterization of Class 1 Integrons and Antibiotic Resistance Genes in Salmonella enterica isolated from Chicken. Global Veterinaria 2017; 18 (5): 322-31.

39. Gast R K. Paratyphoid infections. In D. E. Swayne (Ed.), Diseases of Poultry,

Ames, IA: Wiley-Blackwell Publishing 2013; 693-733.

40. Neubauer H, Hensel A, Aleksic S, Meyer H. Identification of Yersinia enterocolitica within the genus Yersinia. Syst Appl Microbiol 2000; 23(1): $58-62$.

41. Mohamed NS. A survey of Salmonella contamination in chicken carcass and giblets in central Ethiopia. Revue de Med Vet 2003; 154(4):267-70. 
42. Ahmed AM, Shimamoto T. Genetic analysis of multiple antimicrobial resistance in Salmonella isolated from diseased broilers in Egypt. Microbiol Immunol 2012; 56 (4): 254-61.

43. García C, Soriano JM, Benítez V, CataláGregori P. Assessment of Salmonella spp. in feces, cloacal swabs, and eggs (eggshell and content separately) from a laying hen farm. Poult Sci 2011; 90 (7):1581-5.

44. Ren D, Chen P, Wang Y, Wang J, Liu H, Liu $\mathrm{H}$. Phenotypes and antimicrobial

resistance genes in Salmonella isolated from retail chicken and pork in Changchun, China. J Food Saf 2017; 37 (2): e12314.

45. Zhu Y, Lai H, Zou L, Yin S, Wang C, Han X, Xia X, Hu K, He L, Zhou K, Chen S, Ao X, Liu $\mathrm{S}$. Antimicrobial resistance and resistance genes in Salmonella strains isolated from broiler chickens along the slaughtering process in China. Int J Food Microbiol 2017; 259:43-51.

46. Begum K, Mannan SJ, Ahmed A. Antibiotic Resistance, Plasmids and Integron Profile of Salmonella Species Isolated from Poultry Farm and Patients. Dhaka Univ. J Pharm Sci 2016; 15(2): 209 14.

47. Asif M, Rahman H, Qasim M, Khan TA, Ullah W, Jie Y. Molecular detection and antimicrobial resistance profile of zoonotic Salmonella Enteritidis isolated from broiler chickens in Kohat, Pakistan. J Chin Med Assoc 2017; 80(5):303-6.

48. Abdel-Maksoud M, Abdel-Khalek R, ElGendy A, Gamal RF, Abdelhady HM, House BL. Genetic characterisation of multidrug-resistant Salmonella enterica serotypes isolated from poultry in Cairo, Egypt. Afr J Lab Med 2015; 4 (1):158-65.

49. Abatcha MG, Mohd EE, GulamR. Prevalence, antimicrobial resistance, resistance genes and class 1 integrons of Salmonella serovars in leafy vegetables, chicken carcasses and related processing environments in Malaysian fresh food markets. Food Control 2018; 91: 170-80.

50. Álvarez- Fernandez E, Alonso-Calleja C,García-Fernández C, Capita R. Prevalence and antimicrobial resistance of Salmonella serotypes isolated from poultry in Spain: comparison between 1993 and 2006. Int J food Microbiol 2012; 153 (3): 281-7.
51. Ahmed AM, Younis EE, Ishida Y, Shimamoto T. Genetic basis of multidrug resistance in Salmonella enterica serovars Enteritidis and Typhimurium isolated from diarrheic calves in Egypt. Acta Trop 2009; 111(2): 144-9.

52. Elmonir W, Hegazym AM, El-Tras WF, Shohiep A. Extremely drug-resistant Salmonella in broiler production chain in Egypt. Life Sci J 2017; 14(9): 82-7.

53. Zishiri OT, Mkhize N, Mukaratirwa S. Prevalence of virulence and antimicrobial resistance genes in Salmonella spp. isolated from commercial chickens and human clinical isolates from South Africa and Brazil. Onderstepoort J Vet Res 2016; 83(1): 1-11.

54. Gharieb RM, Tartor YH, Khedr MH. NonTyphoidal Salmonella in poultry meat and diarrhoeic patients: prevalence, antibiogram, virulotyping, molecular detection and sequencing of class I integrons in multidrug resistant strains. Gut Pathog 2015;7:34.

55. Lee MF, Chen YH, Peng CF. Molecular characterisation of class 1 integrons in Salmonella enterica serovar Choleraesuis isolates from southern Taiwan. Int J Antimicrob Agents 2009; 33(3): 216-22.

56. De Lappe N, O'Halloran F, Fanning S, Corbett-Feeney G, Cheasty T, Cormican M. Antimicrobial resistance and genetic diversity of Shigella sonnei isolates from western Ireland, an area of low incidence of infection. J Clin Microbiol 2003; 41(5):1919-24.

57. Alghoribi MF, Balkhy H, Doumith M, Al Johani SM, Upton M, Woodford N, Ellington MJ. Molecular Epidemiology, Virulence Potential and Antibiotic Susceptibility of the Major Lineages of Uropathogenic Escherichia coli. Ph.D. thesis, Faculty of Medical and Human Sciences, Manchester Univ, 2015.

58. Ye L, Li R, Lin D, Zhou Y, Fu A, Ding Q, Chan EW, Yao W, Chen S. Characterization of an IncA/C Multidrug Resistance Plasmid in Vibrio alginolyticus. Antimicrob Agents Chemother 2016; 60(5):3232-5.

59. Goodacre NF, Gerloff DL, Uetz P. Protein domains of unknown function are essential in bacteria. mBio 2013; 5(1):e00744-13. 